\title{
Estimation of Profitability of a Company in PT. ABC Using Kalman Filter
}

\author{
Mohamad Yusak Anshori ${ }^{1}$, Teguh Herlambang ${ }^{2}$, Denis Fidita Karya ${ }^{1}$, Dinita Rahmalia ${ }^{3}$ \\ \{yusak.anshori@unusa.ac.id ${ }^{1}$, teguh@unusa.ac.id ${ }^{2}$ \} \\ Management Department, University of Nahdlatul Ulama Surabaya ${ }^{1}$, Information System \\ Department, University of Nahdlatul Ulama Surabaya ${ }^{2}$, Mathematics Department, University of Islam \\ Darul Ulum Lamongan ${ }^{3}$
}

\begin{abstract}
Profitability is a company's ability to earn profits. The higher the profitability is, the more profits the company makes. Profit ratio is the ability or outcome performed or achieved by the company in the sale of goods or services produced or performed in a certain period. Considering that profitability is an important factor in the company, this study focused on the company profitability estimation to determine the increases in profit and loss of a company. The estimation in this study used the Kalman Filter method with the application of the principle of continual prediction and correction. The results of the simulation analysis proved that with 200, 300 and 400 iterations, it had an errror of less than $3 \%$, and with 400 iterations it had higher accuracy than those with 200 and 300 iterations.
\end{abstract}

Keywords: Profitability, profit estimation, Kalman Filter

\section{Introduction}

Profitability is company's ability to make a profit [1]. Kamil and Herusetya argue that higher profitability indicates that the company is able to make more profits [2]. Thus, the company is able to increase social responsibility activities, and disclose its social responsibility in an annual report more extensively. Profitability is usually measured by return on assets (ROA), usually expressed as a function of internal and external determinants. Internal determinants are mainly influenced by bank management decisions and policy objectives, the determinants of profitability are the level of liquidity, provision, capital adequacy, management costs and bank size.

Profitability ratio is the ability of or the results achieved by the company in the sale of goods or services produced in a certain period. To make a decision regarding the sale of goods or services to make a profit, estimation of profit and loss to be obtained in the future is required. The correct way of analysis that reduces the risk of sales errors is to estimate the company's profit. Estimatimation is not only made on profitability, but can also be applied to stock prices $[3,4]$, PRC blood data [5], boiler-level steam drum [6], trajectory of Autonomous Underwater Vehicle (AUV) [7,8], missile movement [9] and estimation of crude oil price [10]. Estimation is made because a problem is likely to be able to be solved using previous information or data related to the problem $[3,7]$. Kalman Filter is applied through two stages, that is, predicting state 
variables based on dynamic system called prediction (time updates) and the measurement update over measurement data to improve the estimation results [8]

The objective of the study is to estimate the profit function obtained from Mathematica software simulation which is then simulated with the Matlab software. In this paper the application of the Kalman Filter method in estimating company profits can be used as a reference to consider for the company's activities in sales and purchases so that it can reduce company losses.

\section{Kalman Filter Method}

In Kalman Filter, estimation is made into two stages, that is, by predicting state variable based dynamic system called prediction (time update) stage and then correction (measurement update) stage. For the application of Kalman Filter, estimation is made in two stages, that is, by predicting state variables based on dynamic systems called the prediction stage (time updates) and the measurement update for measurement data to improve estimation results.

The prediction stage is influenced by the dynamics of the system by predicting state variables using the estimation equation of state variables and the accuracy level is calculated using the covariance error equation. In the correction phase the estimation results of state variables obtained at the prediction stage are corrected using a measurement model [11]. The Kalman Filter algorithm is shown:

\section{System Model and Measurement Model}

$$
\begin{aligned}
& x_{k+1}=A_{k} x_{k}+B_{k} u_{k}+G_{k} w_{k} \\
& z_{k}=H_{k} x_{k}+v_{k} \\
& x_{0} \sim N\left(\bar{x}_{0}, P_{x_{0}}\right) ; w_{k} \sim N\left(0, Q_{k}\right) ; v_{k} \sim N\left(0, R_{k}\right)
\end{aligned}
$$

Initialization

$$
\begin{aligned}
& \hat{x}_{0}=\bar{x}_{0} \\
& p_{0}=p_{x_{0}}
\end{aligned}
$$

\section{Prediction Stage}

Estimation $\quad: \hat{x}_{k+1}{ }^{-}=A_{k} \hat{x}+B_{k} u_{k}$

Covarian error : $P_{k}^{-}=A_{k} P_{k} A_{k}^{T}+G_{k} Q_{k} G_{k}^{T}$ 


\section{Correction Stage}

Kalman

Gain

$K_{k+1}=P_{k+1}^{T} H_{k+1}^{T}\left(H_{k+1} P_{k+1}^{-} H_{k+1}^{T}+R_{k+1}\right)^{-1}$

Estimation $\quad: \hat{x}_{k+1}=\hat{x}_{k+1}^{-}+K_{k+1}\left(z_{k+1}-H_{k+1} \hat{x}_{k+1}^{-}\right)$

Covarian error : $P_{k+1}=\left[I-K_{k+1} H_{k+1}\right] P_{k+1}^{-}$

\section{Simulation Results And Analysis}

In this paper the estimation of stock price was made by using the Kalman Filter (KF) method with 200, 300 and 400 iterations. This simulation used and the initial value of the stock price. Profit data at PT. The ABCs in Table 2 are interpolated with Mathematica software so that it produces a profit function in equation (1)

In this paper the estimation of stock price was made by using the Kalman Filter (KF) method with 200, 300 and 400 iterations. This simulation used $\Delta t=0,1$ and the initial value of the stock price. The profit data at PT. The ABCs in Table 1 are interpolated with Mathematica software so that it produces a profit function in equation (1).

Table 2. Profit Data of PT.ABC (in million)

\begin{tabular}{cc}
\hline Month & Company profit \\
\hline 1 & 301 \\
2 & 286 \\
3 & 271 \\
4 & 285 \\
5 & 282 \\
6 & 261 \\
7 & 310 \\
8 & 290 \\
9 & 297 \\
10 & 278 \\
11 & 321 \\
12 & 294 \\
13 & 315 \\
14 & 302 \\
15 & 318 \\
16 & 299 \\
17 & 297 \\
18 & 281 \\
19 & 321 \\
20 & 298 \\
21 & 315 \\
22 & 309 \\
23 & 319 \\
\hline
\end{tabular}




\begin{tabular}{ll}
\hline 24 & 314 \\
25 & 316 \\
\hline
\end{tabular}

Then, the table 1 are interpolated using Mathematica software, so as to obtain the company's profit function as follows:

$$
\begin{aligned}
& f_{\text {close }}(x)=105,67 x^{2}-421,35 x+8021,56 \\
& f^{\prime}{ }_{\text {close }}(x)=211,34 x-421,35
\end{aligned}
$$

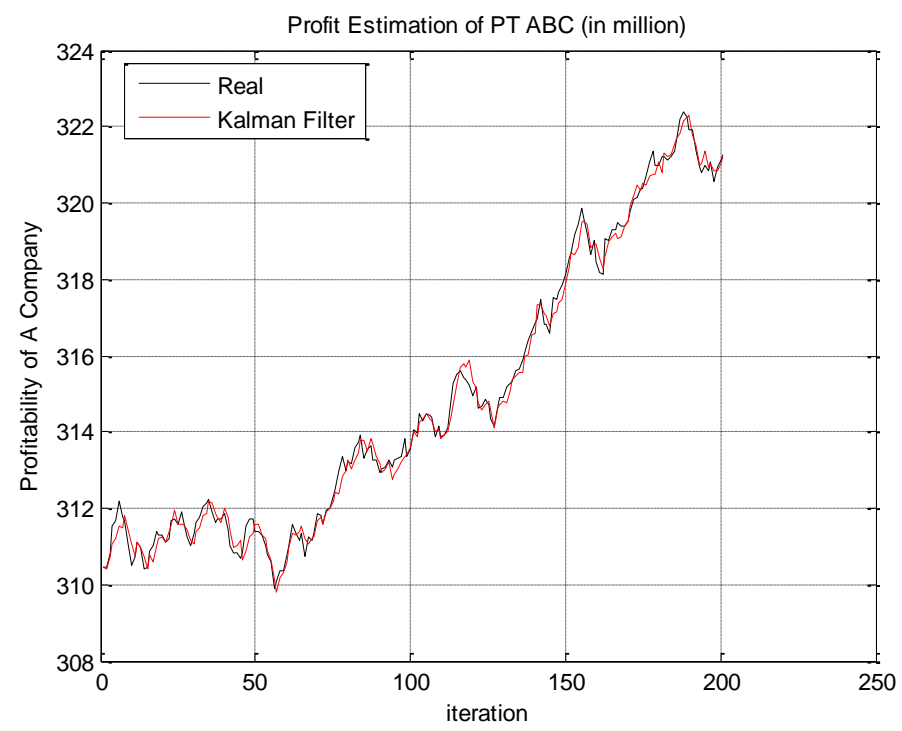

Figure 1 Profit Estimation of PT. ABC with 200 iterations

Figures 1, 2 and 3 explain the simulation results on the estimation of company profits of PT. ABC using 200, 300 and 400 iterations. In Figures 1, 2 and 3 show that the results of estimation of profit have a pattern that is almost the same as the stock price in the field (real), whereas the stock price estimation using the KF method has a high accuracy with an error of less than 3\%. The error obtained is 0.29535 in the simulation with 200 iterations. Whereas with 300 iterations it produces an error of 0.28783 , and the error obtained in the that with 400 iterations is 0.27601 as shown in Table 2. Further, the comparison of the estimation results with 200, 300 and 400 iterations, Table 2 shows that the simulation with 400 iterations has a higher accuracy than those with 200 and 300 iterations. From the error obtained, it can be concluded that the KF method can be applied to estimate the profit of a company with a relatively small error. 


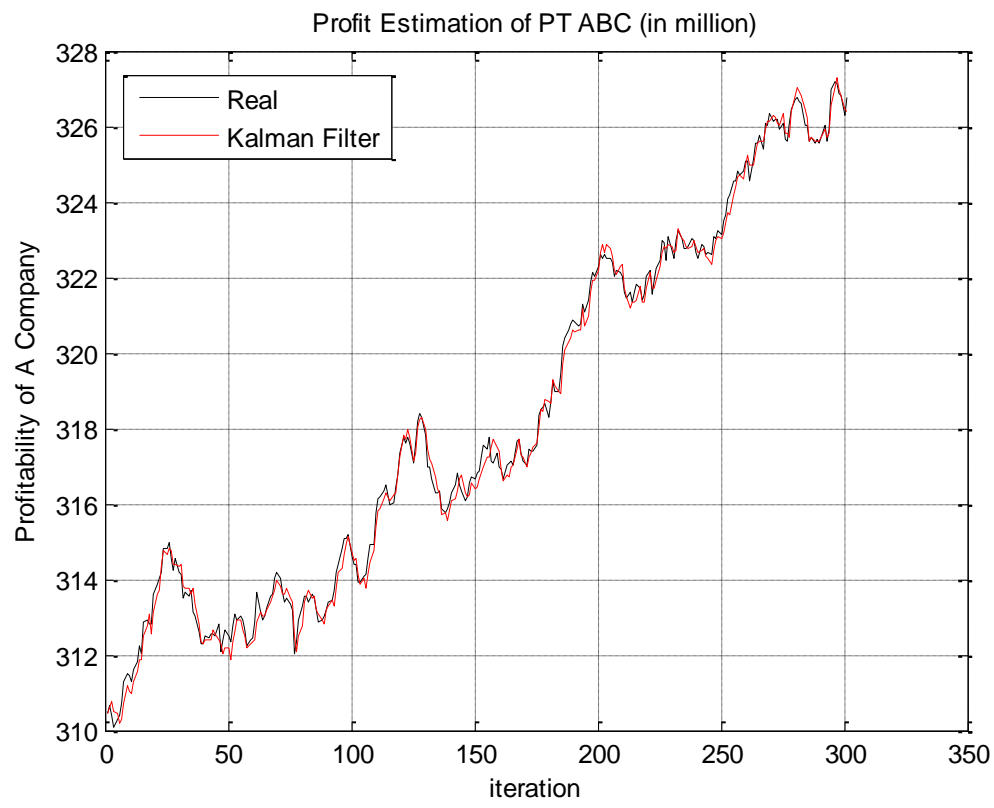

Figure 2. Profit Estimation of PT. ABC with 300 iterations

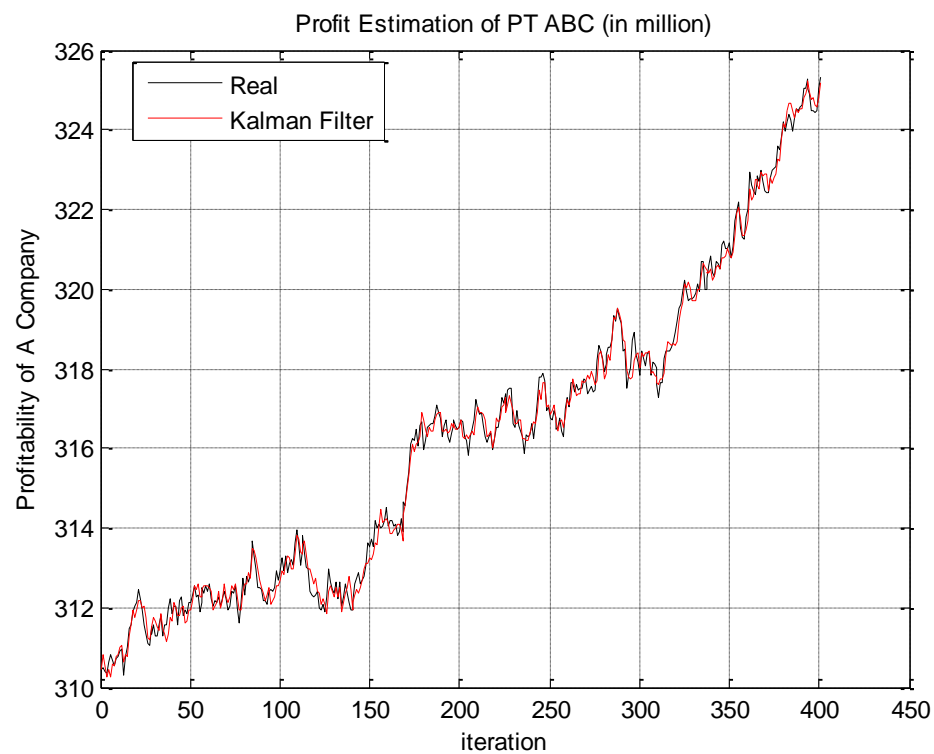

Figure 3. Profit Estimation of PT. ABC with 400 iterations 
the comparison of the estimation results with 200, 300 and 400 iterations as follow in Table 3:

Table 3. Comparison of RMSE values using Kalman Filter Method by 200, 300 dan 400 iterations

\begin{tabular}{lccc}
\hline & 200 iterations & 300 iterations & 400 iterations \\
\hline Company profit & 0.29535 & 0.28783 & $\mathbf{0 . 2 7 6 0 1}$ \\
Simulation time & $4.5312 \mathrm{~s}$ & $6.2189 \mathrm{~s}$ & $8.3557 \mathrm{~s}$ \\
\hline
\end{tabular}

Further, the comparison of the estimation results with 200, 300 and 400 iterations in Table 3 shows that with 400 iterations it is accurate to estimate the profit of a company. In terms of simulation time, with 200 iterations it has a faster time than those with 300 and 400 iterations because the number of iterations greatly affects computation time. From the results of analysis, the simulations with 200, 300 and 400 iterations have errors of less than $3 \%$, so the Kalman Filter method can be used as one method of estimating company profits.

\section{Conclusion}

Based on the results of the analyses of the simulations with 200, 300 and 400 iterations, the Kalman Filter method can be used to estimate the profitability function of a company with a high degree of accuracy and an error of around $2 \%-3 \%$.

\section{References}

[1] Kartini dan Tulus Arianto. 2008. Struktur Kepemilikan, Profitabilitas, Pertumbuhan Aktiva Dan Ukuran Perusahaan Terhadap Struktur Modal Pada Perusahaan Manufaktur. Jurnal Keuangan Dan Perbankan, 12(1), h: 11 - 21.

[2] Kamil, Ahmad dan Antonius Herusetya. 2012. Pengaruh Karakteristik Perusahaan Terhadap Luas Pengungkapan Kegiatan Corporate Social Responsibility. Media Riset Akuntansi, 2(1), h: 1-17.

[3] Karya, D.F., Puspandam, K. and Herlambang, T., 2017. "Stock Price Estimation Using Ensemble Kalman Filter Square Root Methods", The First Internatonal Conference on Combinatorics, Graph Teory and Network Topology, University of Jember-Indonesia, 25-26 Nov 2017, Journal of Physics: Conf. Series 1008 (2018) 012026.

[4] Karya, D.F., Puspandam, K., Herlambang, T., and Rahmalia D., 2018. "Development of Unscented Kalman Filter Algorithm for stock price 
estimation", The Second Internatonal Conference on Combinatorics, Graph Teory and Network Topology, University of Jember-Indonesia, 24-25 Nov 2018, Journal of Physics: Conf. Series 1211 (2019) 012031.

[5] Shanty, W., Firdaus., Herlambang, T., 2018. "Prediction of Availability of Packed Red Cells (PRC) at PMI Surabaya City Using Ensemble Kalman Filter as Management of Blood Transfusion Management", The Second Internatonal Conference on Combinatorics, Graph Teory and Network Topology, University of Jember-Indonesia, 24-25 Nov 2018, Journal of Physics: Conf. Series 1211 (2019) 012031

[6] Herlambang, T., Mufarrikoh, Z., Fidita, D.F., Rahmalia, D., 2017. "Estimation Of Water Level And Steam Temperature In Steam Drum Boiler Using Ensemble Kalman Filter Square Root (EnKF-SR)", The First Internatonal Conference on Combinatorics, Graph Teory and Network Topology, University of Jember-Indonesia, 25-26 Nov 2017, Journal of Physics: Conf. Series 1008 (2018) 012026.

[7] Herlambang, T., Djatmiko E.B and Nurhadi H., 2015, "Ensemble Kalman Filter with a Square Root Scheme (EnKF-SR) for Trajectory Estimation of AUV SEGOROGENI ITS", International Review of Mechanical Engineering IREME Journal, Vol. 9, No. 6. Pp. 553-560, ISSN 1970 - 8734. Nov.

[8] Herlambang, T., Djatmiko E.B and Nurhadi H., 2015, "Navigation and Guidance Control System of AUV with Trajectory Estimation of Linear Modelling", Proc. of International Conference on Advance Mechatronics, Intelligent Manufactre, and Industrial Automation, IEEE , ICAMIMIA 2015,Surabaya, Indonesia, pp. 184-187, Oct 15 - 17.

[9] Herlambang, T., 2017, "Design of a Navigation and Guidance System of Missile with Trajectory Estimation Using Ensemble Kalman Filter Square Root (EnKF-SR). International Conference on Computer Applications and Information Processing Technology (CAIPT)-IEEE, Bali Indonesia 8-10 Augsut 2017.

[10] Puspandam, K., Fidita, D.F., Herlambang, T.,and Khusnah,H., 2018. "Ensemble Kalman Filter for Crude Oil Price Estimation,", The Second Internatonal Conference on Combinatorics, Graph Teory and Network Topology, University of Jember-Indonesia, 24-25 Nov 2018, Journal of Physics: Conf. Series 1211 (2019) 012031 